\title{
Students as Partners-Good for Students, Good for Staff: A Study on the Impact of Partnership Working and How This Translates to Improved Student-Staff Engagement
}

Roisín Curran, Centre for Higher Education Research and Practice, Ulster University, Northern Ireland, United Kingdom.

Contact: r.curran@ulster.ac.uk

\section{ABSTRACT}

This paper situates Students as Partners (SaP) within the broader construct of student engagement so that we can examine the influence of partnership on student and staff participants and how this impacts on student and staff relationships. The findings of interviews carried out with students and staff $(n=14)$, which aimed to capture rich descriptions of the lived experience of individuals, reveal that there was a high level of consensus between students and staff on how they described their lived experiences and the impact that partnership was having on them-particularly in relation to their personal development. Whilst it became apparent that the participants' thinking and behaviours had changed as a result of their involvement in partnership, quite often the catalyst for this change was in relation to how the participants were feeling. Considerations for relevant stakeholders are highlighted to support the scaling up of a SaP approach.

\section{KEYWORDS}

students as partners, student-staff partnership, higher education, personal development, scaling up partnership

\section{INTRODUCTION AND RATIONALE FOR THE STUDY}

According to Gibbs $(2014 ; 2016)$ student engagement (SE) is a slippery construct and a current buzzword used by higher education institutions (HEIs), students' unions, teaching development units, and government alike. The difficulty that this presents is that "student engagement has come to be used to refer to so many different things that it is difficult to keep track of what people are actually talking about" (Gibbs, 2016, p. 1). There are differing ways to view SE, and these vary according to an individual's role as either student or staff, discipline, beliefs, context, research perspective, and even country (Bryson, 2014a; Harrington, Sinfield \& Burns, 2016; Kahu, 2013). In addition, following the dramatic rise of 
mass forms of higher education (HE), SE has become problematic (Kahn, 2014), and this study sought to explore the impact of student-staff partnerships on the individual through an appreciation and interpretation of the lived experiences of students and staff to determine the extent to which partnership influences student engagement. This is important in the context of the massification of $\mathrm{HE}$, which has seen student numbers increase worldwide by 51.7 million between 2000 and 2008 (UNESCO, 2009). Coates and McCormick (2014) state that as student populations in many countries become larger and more diverse, there is a growing need to understand how to engage students across the student lifecycle. Scullion, Molesworth, and Nixon (2011) argue that an outcome of the marketisation of HE has resulted in students adopting a passive role in their learning where $\mathrm{HE}$ is viewed as a commodity and a "student as consumer" ( $\mathrm{SaC}$ ) attitude prevails. Many scholars (e.g., Bryson, 2014a; 2014b; Levy, Little, \& Whelan, 2011; Matthews, 2016; McCulloch, 2009) feel that the time has come to challenge this paradigm and to move away from hierarchical university structures that encourage a "them and us" attitude to more collaborative approaches where students and staff work together for the mutual benefit of both in pursuit of deep learning.

McCulloch (2009) criticised the SaC model, finding at least eight deficiencies with it that reduced the role of the student to that of a passive recipient. He proposed that considering students as co-producers places the student in a more active role and encourages a "students as partners" (SaP) attitude. More recently, Healey, Flint, and Harrington (2014) state that

partnership is understood as fundamentally about a relationship in which all involved-students, academics, professional services staff, senior managers, students' unions, and so on-are actively engaged in and stand to gain from the process of learning and working together. Partnership is essentially a process of engagement, not a product. It is a way of doing things, rather than an outcome in itself. (p. 12)

Bryson (2014b) concurs with this approach and believes that "partnership and all that it entails offers the most fruitful way forward for student engagement as so many of the good practices for engaging students ... resonate with the principles and practices of partnerships" (p. 239).

The recent move towards promoting a partnership ethos between students and staff across the sector has resulted in many institutions forging ahead with initiatives spanning various aspects of university life. As a consequence, different types of partnership have emerged and the diversity these embody would appear to support findings of studies in the public sector (Cook, 2015) and in the HE sector (Cook-Sather, Bovill, \& Felten, 2014) that there is "no one size fits all" when it comes to partnership working.

Working collaboratively is, of course, not new, and we are reminded that the idea of a university with a community of learners (students and staff) working together to advance scholarship was the vision put forward by Wilhelm von Humboldt in 1810 when he founded the University of Berlin (Lea, 2016; Levy, Little, \& Whelan, 2011). More recently, research has emerged that extols the virtues of the SaP paradigm encompassing the following capacities. It focuses on the development of the learner leading to improved citizens (McCulloch, 2009). It enhances motivation and learning (Cook-Sather, Bovill, \& Felten, 2014; Little et al., 2011; Nygaard, Brand, Bartholomew, \& Millard, 2013). It develops metacognitive awareness and sense of identity (Cook-Sather et al., 2014; Dickerson, Jarvis, \& Stockwell, 2016; Nygaard et al., 2013). It improves teaching and the classroom 
experience, which prompts a learning community (Cook-Sather et al., 2014; Curran \& Millard, 2015; Nygaard et al., 2013). It improves learning in relation to employability skills and graduate attributes (Dickerson, Jarvis, \& Stockwell, 2016; Pauli, Raymond-Barker, \& Worrell, 2016).

However, whilst this research highlights the outcomes of partnership working in a positive light, it is important to acknowledge the challenges that this type of working presents. It is clear that genuine partnerships do not happen automatically and questions still remain-particularly if we wish to scale up partnership working across an institution. Consideration is needed on how we can reconcile power relations between students and staff when we are working in a dominant SaC ideology (Delpish et al., 2009; Hutchings, Bartholomew, \& Reilly, 2013; Levy et al., 2011). Transience can be a barrier as partners move on (Little et al., 2011; Levy et al., 2011), as can sustaining partnership work (Curran \& Millard, 2015). There is also the challenge of finding a common language (Cook-Sather et al., 2014; Levy et al., 2011). SaP can be a threshold concept for both students and staff (CookSather, 2014; Marquis et al., 2016). Finally, finding time and funding for SaP can present a stumbling block (Marquis, Black, \& Healey, 2017).

Despite and in recognition of the challenges, there is a growing movement across the $\mathrm{HE}$ sector to capitalise on the benefits of SaP in order to fully realise what some claim (see, e.g., Cook-Sather et al., 2014; Healey et al.,2014) is the potential transformative nature of a culture change that challenges the customer-provider model of HE. However, scaling up partnership working so that it challenges traditional forms of SE, which position the student in a passive role, to more relational forms of SE (Flint, 2016; Matthews, 2016), means that we need to consider our SE approaches more holistically by considering all of their component parts. Three dimensions of SE have been identified in the literature: behavioural engagement, emotional engagement, and cognitive engagement (Solomonides, 2013; Kahu, 2013; Trowler, 2010; Fredricks, Blumenfeld, \& Paris, 2004). These scholars state that students who are behaviourally engaged would typically comply with behavioural norms, such as attendance and involvement. Students who engage emotionally would experience affective reactions such as interest, enjoyment, or a sense of belonging. Cognitively engaged students would be invested in their learning, would seek to go beyond the requirements, and would relish challenge.

Recent research suggests that it is the interplay between the three dimensions at the level of the individual student that is important and is that which would allow us, as teachers and institutions, to examine what is within our control and what is not so that we might clearly focus on what we can enhance (Solomonides, 2013). However, Kahu (2013) cautions that when "positioning engagement so clearly with the individual, there is a danger of downplaying the importance of the situation. Engagement is fundamentally situationalit arises from the interplay of context and individual" (p. 763).

\section{THEORETICAL FRAMEWORK}

In this paper, SaP is situated within the broad term SE and is viewed as a process or a concept in which to frame collaborative working between students and staff for the mutual benefit of enhancing learning and teaching. The focus for the research under discussion here is on an aspect of SE-staff and student relationships-defined as "psychosocial influences" in Kahu's model of socio-cultural influences on SE (Kahu, 2013, p. 766), represented in Figure 1. 
Figure 1: Conceptual framework of engagement, antecedents, and consequences (Kahu, 2013, p. 766)

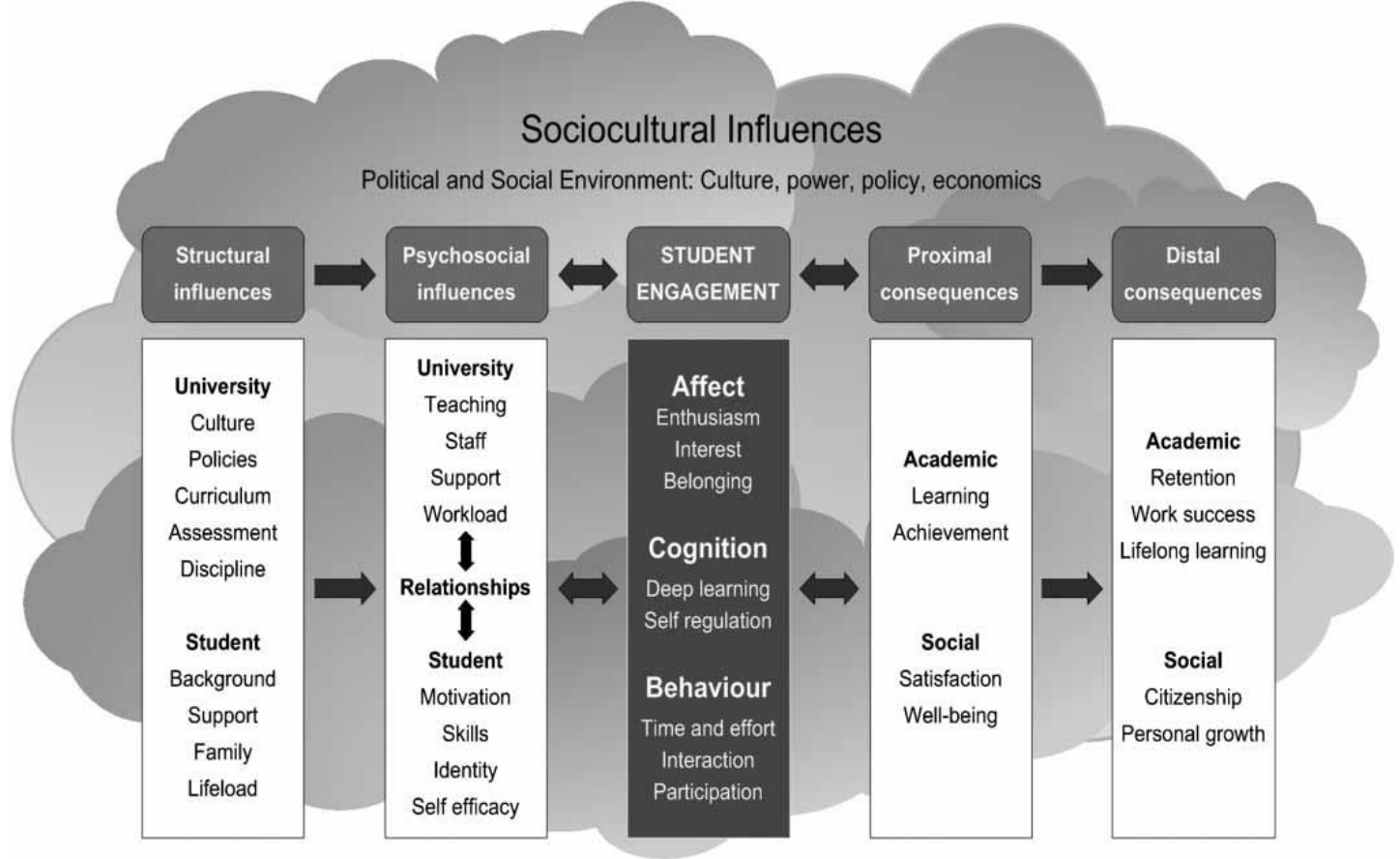

Kahu (2013) places the student at the centre, as depicted by the centre column, and includes the three dimensions of SE representing the psychological: affect, cognition, and behaviour. In order to highlight the impact of sociocultural factors, the two columns on the left side of the figure represent the influencing factors, or antecedents, of the university and of the student. The psychosocial influences, which include university and student attributes and the relationships between them, are depicted as having a clear impact on SE and as being influenced by SE. The double-sided arrows between these two columns draw attention to this. In other words, the building of relationships between staff and students can influence SE, and SE can further build relationships. The consequences of SE are depicted by the two columns on the right side of the figure and are divided into what happens in academic and social spheres (also identified by Tinto, 1987, and Thomas, 2012). Again, the double-sided arrow between the central column and the proximal consequences indicate that student success or deep learning and the feeling of well-being may further influence SE, which in turn may result in more distal consequences such as retention and a disposition for lifelong learning and active citizenship.

Cognisant of my role as an academic developer in building staff and student capacity to engage, the overarching question this study attempts to address is: What is the impact of SaP on the individual staff and student participants involved and to what extent does this influence how they engage?

\section{RESEARCH CONTEXT}

Kahu (2013) advises that her framework (see Figure 1 above) "highlights the need for projects that focus on narrower populations, including single institutions, as it is evident that a broad generalization of the student experience is ill-advised"(p. 769). She also advocates for "the use of in-depth qualitative methodologies to capture the diversity of experience" (p. 769). The data drawn upon in this paper were collected as part of a research project that set out to explore the lived experiences of students and staff at Ulster University who were one of 13 institutions across the four countries of the UK involved in 
the What Works? Student Retention and Success Change Programme 2013-2016 (WWSRS). One of the overarching aims of this Change Programme was to enhance the strategic approach to improving the engagement, belonging, retention, and success of students. The WWSRS at Ulster University involved a core team and seven discipline teams (representing 145 participants: 94 students and 51 staff). The discipline teams were Accounting; Built Environment; Computing; Creative Technologies; Law; Nursing (Mental Health); and Textile Art, Design, and Fashion. These seven teams comprised the course staff team and a number of students from the first, second, and final year of the undergraduate programmes. In order to achieve the objectives of the programme, the core and discipline teams were engaged in a range of activities between 2013 and 2016. The teams implemented specific interventions in the areas of first-year student induction (e.g., pre-arrival activities), active learning (e.g., higher-level students coaching first-year students), and co-curricular activities (e.g., workshops involving students from different year groups). This was followed by qualitative evaluation of the interventions, the administration of "belonging surveys" with students involved in the programme, and the use of institutional data such as attrition rates for each of the areas to monitor impact as a result of the interventions.

\section{RESEARCH METHODS}

In order to address the research question highlighted above, an in-depth qualitative methodology was employed to capture the diversity of experience across the disciplines involved. One-to-one semi-structured interviews were carried out and recorded with staff and students $(n=14)$, which aimed to capture rich descriptions of the lived experience of individuals. Purposive sampling was used and the individual interviews included one staff and one student member from each of the seven discipline teams. A member of staff and a student from the participant group indicated above assisted me in the development of trigger questions for the interviews (listed below). We carefully considered the questions posed in order to invoke descriptions of lived experiences and to "choose formulations which were open (rather than closed), and which do not make too many assumptions about the participant's experiences or concerns, or lead them towards particular answers" (Smith, Flowers, \& Larkin 2009, p. 60). Additionally, we wanted to use more "how" questions rather than "why" questions to ensure that the questions prompted rich descriptions of experience rather than overly reflective or intellectualised responses (Husserl, 1999; Kvale, 2007; van Manen, 1990).

\section{Semi-structured interview trigger questions}

1. How do you feel about staff student partnerships?

2. Has the development of the staff student partnership in which you are involved presented any opportunities and/or challenges? If so, could you describe them?

3. Have you seen any differences in the way you interact with staff/students since the partnership was introduced? If so, could you describe them?

4. Has the staff student partnership changed your approach to your studies/teaching practice? If so, how?

5. Any further comments?

Following data collection, interview recordings were transcribed for data analysis. My approach focused on how I could tell the story of participants' lived experiences in relation to the broad challenge of SE. I was mindful that I needed to make the participants' experiences come to life and avoid "deadening" the phenomenon with bland descriptions, and that there is no one correct way to do the analysis (Finlay, 2014). Deep understanding 
of the meanings of data of this nature can be implicit and need to be made explicit with thematic analysis (Waters, 2016); hence, I engaged in a six-stage approach to thematic analysis as detailed by Braun and Clarke (2006). Undertaking each phase allowed me to examine the data set (transcribed interviews). At stage 1,1 read and re-read all the transcripts and noted down initial ideas. During the coding process of stage 2, 97 individual codes were identified; these represented features of the data across the data set. Further exploration of these initial codes enabled me to identify repetition and grouping of codes. In stage 3, I collated codes into potential themes, gathering all the data relevant to each theme. The original 97 codes were reduced by combining those that were similar and were then categorised under themes, which represented the remaining codes. It became evident that there were similarities between what students and staff were describing in relation to how their thinking was changing as new skills were developing and how these changes were resulting in a change in practice. Additionally, there was an acknowledgment of the challenges presented in "doing" staff-student partnership. In moving to stage 4, I checked if the themes worked in relation to the coded extracts (the original 97 codes) and the entire data set. The ongoing analysis in stage 5 allowed me to refine the specifics of each theme and the overall story that the analysis tells. At this point, I defined and further refined the themes; two dominant themes were named, along with clear definitions for each. Figure 2 below presents the main themes with their sub-themes and provides the basis for organising the results below.

\section{RESULTS}

The data revealed that whilst individual participants experienced partnership in nuanced ways, there was a striking degree of accord in the descriptions of the impact of the partnership on the individual. This is explored under the identified themes displayed in Figure 2. Additionally, there was an acknowledgment of the challenges presented in doing SaP.

Figure 2. Thematic map showing main themes and sub-themes
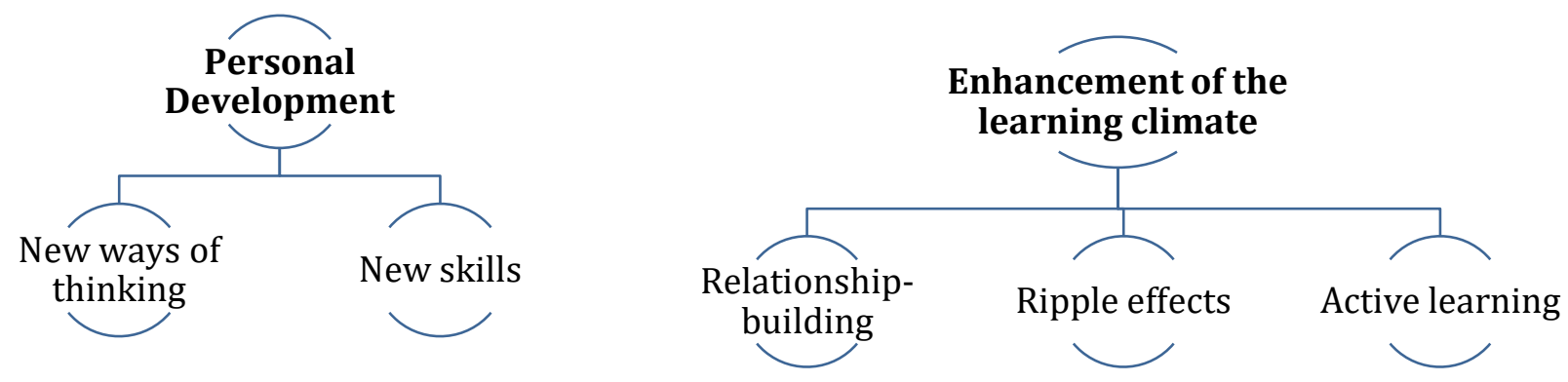

\section{Personal development}

Theme 1 was identified as personal development. In this context, it relates to personal development of the individual, and Aubrey (2010) defines it thus: "Personal development covers activities that improve awareness and identity, develop talents and potential, build human capital and facilitate employability, enhance quality of life, and contribute to the realization of dreams and aspirations. (p. 9) 
The interviews provided an opportunity for participants to describe their lived experience of working in a SaP context. It became clear that for some students and staff the impact of partnership on them personally came as a surprise and not something they had thought would happen because of their involvement. Descriptions provided by participants related to how their self-awareness and self-knowledge was improving. There was also evidence in the descriptions (e.g., how participants were describing their role) of a shift in identity related to this new knowledge, and many described this shift resulting from increased confidence in their role. For those whose identity had shifted, there was a willingness to try new ideas and to try to enhance what they do or had been doing for many years.

\section{New ways of thinking}

Staff and students also commented on how the partnership encouraged dialogue and mutual feelings of respect. It gave both an insight into the others' world that enabled them to become more open and to consider new ways of thinking.

One student commented on the change she was experiencing as a result of being involved in the project with staff:

I have developed confidence as a result of this and I feel more like a member of staff as I have got to know all the staff so well. Last year I was very quiet as a student coach. This opportunity allows me to develop my teaching skills as I was coaching first years that were having difficulty in one of the modules. I have developed my own knowledge through interactions with first year students and I can see the development in their confidence too. (Year-4 student, discipline 4)

A tutor described how they had always thought of staff and student roles in very defined terms but that working with students had made him realise that today's students are different: "I've had this sense of letting go-somebody has labelled me as an expert, but the students are the experts in their experience" (Tutor, discipline 5).

\section{New skills}

Students and staff demonstrated how involvement in partnership allowed them to engage in activities both inside and outside of the classroom. The collaborative tasks were allowing them to develop not just confidence but new skills too. One student commented: "The residential was very good-it was great to attend a professional event. Discussions with lecturers and co-presenting is helping me develop as a person and it will be great for job interviews" (Year-2 student, discipline 7).

A staff member described partnership work in HE as more reflective of the world of work, particularly in health-related disciplines where partnership is promoted between staff and users: "From a professional point of view it works well for me, partnership mimics the profession-we are teaching our students to work in partnership with service users" (Tutor, discipline 5).

\section{Enhancement of the learning climate}

Theme 2 relates to the context in which student learning occurs and the enhancement thereof. Ambrose, Bridges, DiPietro, Lovett, and Norman (2010) define the learning climate as

the intellectual, social, emotional, and physical environments in which our students learn. Climate is determined by a constellation of 
interacting factors that include faculty-student interaction, the tone instructors set, instances of stereotyping or tokenism, the course demographics (for example, relative size of racial and other social groups enrolled in the course), student-student interaction, and the range of perspectives represented in the course content and materials.

All of these factors can operate outside as well as inside the classroom.

(p. 170)

The interviews also indicated the value of this work in developing staff and student capacity to engage. Participants described how the learning environment was more "friendly" and they seemed happier because barriers were coming down between students and staff, which allowed scheduled classes to be more interactive. There were numerous references to the interactions that took place inside and outside of the classroom and how getting to know others in one context was transferring to another, thereby enhancing relationships and collegiality. Students and staff described how their practice and their approaches to learning and teaching had changed. The data suggests that working together was a catalyst for the enhancement of the learning climate.

\section{Relationship-building}

For both staff and students there was a realisation that behind the roles that each have that there is a person and getting to know the person helps both to carry out their role more satisfactorily and effectively. Involvment in partnership also led both students and staff to question previously held ideas on the teacher-student relationship and the hierarchy that exists or did exist in previous educational settings. As one student stated:

I'm a student rep and that's how I became involved. I was asked to come to a meeting, it was very friendly and it made me feel like part of a team-not them and us. They kept it all down to earth and not too formal. At the start I didn't know much about it, but I then became aware it's about improving the course for next year. To make it better particularly for revalidation. I can also feedback aspects of the course that aren't working well. (Year-1 student, discipline 6)

\section{Ripple effects}

Creating a ripple effect in this context describes the influence that staff has on SE in relation to their attitude and approach to practice both inside and outside of the classroom. It also describes the influence that students have on other students in relation to their attendance, participation, and engagement in class. One staff member described how events external to the class were influential in the classroom setting:

The social integration on some of the extra-curricular activities was fantastic. The relationships were then carried back into the workshops. One student had assumed that others knew each other and she felt on the outside, but realised they didn't and she was immediately drawn in... seeing that before my very eyes has reminded me of the importance of the need for social integration. (Tutor, discipline 7)

\section{Active learning}

Both students and staff reflected on how the partnership prompted them to reflect on their approach to their practice or their studies. The majority of participants indicated that they had enhanced their approaches as a result of their involvement. For some staff, this 
involved a radical change to how they used the time in the classroom with students, such as moving from a transmission mode of lecturing to a more facilitative mode. One tutor described how their classroom practice had changed:

You notice a difference, it's more open and free in terms of what you can say and they say and it helps with the delivery of the content and you feel more relaxed and they feel more relaxed (Tutor, discipline 3).

Another tutor felt that the partnership was prompting them to reflect on his overall approach to learning, teaching, and assessment:

It's given me an opportunity to sit back and reflect on what do you want to do as a teacher? I've spent more time thinking about what I want to achieve, taking that approach of being a facilitator has given me the space to explore further and rather than trying to cover everything, I can focus on one aspect which causes difficulty and we will focus on this. I can direct the students to the independent study better-it's made me less worry about transmitting information out and focus on how to use class time better. I've become more open to risk-taking in classroom. (Tutor, discipline 5)

\section{Challenges}

Students and staff also identified that partnership working is not without its challenges and these can be found at the individual or discipline level. The descriptions of challenges can be summarized as time, resistance, and capacity. One part-time student described his experience:

When I agreed to do this, I didn't realise there was going to be a residential or set times for meetings. If I realised there would be meetings during daytime hours, I probably would have turned down the opportunity to do this. (Part-time student, discipline 6)

A member of staff explained that whilst partnership working might be instigated or nurtured by individual course tutors, it is difficult when other team members are not so committed: "Overall, I am positive about a partnership approach in the broader sense. There are other staff not engaging in the project and this is not sustainable going forward" (Tutor, discipline 2).

Another student described having difficulty knowing when to put forward a suggestion:

Knowing when to come forward and speak. There always is a divide and that will never change. It's hard to know when your input is valuable and whether or not to sit back. Even if I have idea, I'm never sure whether it's valuable or not. (Year-2 student, discipline 1 )

And for some student partners, involvement in the partnership can put more pressure on them to have the right answers and to do well academically: "I feel that because people [other students] are always asking me things ... about assignments and stuff like that, it almost puts you under pressure to do well" (Year 1 student, discipline 5).

A member of staff also described the difficulty of transitioning to a SaP ethos: Partnership should be two-way and how do you make it two-way. Sometimes, it depends on the students. There are challenges with the rep system and I'm worried that there's a negative perception and 
perspective of a complaint culture. We need to listen to students and taken on board their suggestions but you can feel quite threatened. When they started paying fees, they became customers. (Tutor, discipline 1)

\section{DISCUSSION OF THE FINDINGS AND THEIR IMPLICATIONS IN RELATION TO EXISTING KNOWLEDGE}

The findings can be related to elements of the conceptual framework (Kahu, 2013) (see Figure 1). Under the theme of personal development, staff and students indicated the value of partnership work in providing an opportunity for all participants to develop new ways of thinking and new skills aligning to Aubrey's (2010) definition of personal development as improving self-awareness, self-knowledge, skills, and quality of life. Kahu (2013) refers to this in the psychosocial influencing column of the framework, which indicates that student attributes such as motivation, skills, identity, and self-efficacy all have an impact on SE. It is important to note here, however, that whilst partnership working in this context was enhancing these student attributes and positively impacting $\mathrm{SE}$, there is evidence to suggest that staff attributes were also enhanced and that personal growth was happening for both. This is indicated in the framework as a distal consequence that appears to be limited to students. Indeed, as identified by Mercer-Mapstone et al. (2017), one of the areas where further research is needed is in relation to the outcomes of partnership for staff. The implication of the impact of partnership on staff is worth further consideration particularly if we wish to scale up a SaP ethos as a process of SE across growing and diverse student populations. In this context, perhaps we need to recognize the importance of facilitating personal growth for both staff and students in order that they can engage effectively, rather than just focusing on what staff can do to make students engage. Reflecting on the three dimensions of SE (the central column of the framework) which include behavioural, emotional, and cognitive engagement, it became apparent that within this study the three dimensions are inter-related and work together. Emotion was evident in the descriptions of lived experience, and both staff and students described how they were feeling engaged or motivated or more involved, which was changing their thinking. This in turn was affecting their behaviours. Elder (1996) refers to this as the three basic mental functions: cognition, feelings, and volition operating in a dynamic relationship to each other. Where there is thinking, some related feeling exists.

Under the second theme, enhancement of the learning climate, students and staff talked about the breaking down of barriers and a "them and us" attitude that for some was leading to a better classroom experience. Students felt the benefit of being able to sit down around a table and discuss issues with the staff that make decisions. As indicated by the results, students felt that partnership is very beneficial in bringing staff and students closer together. Similarly, staff described their increased engagement as a result of getting to know the student cohort better. This reinforces what Kahu (2013) indicated under the psycho-social influence: that relationship-building fosters engagement, which in turn builds better relationships. This is potentially very powerful, and we need to consider how staff and students could be supported to initiate and sustain change through dialogue, and not just for some students who happen to be involved in a partnership initiative but for all students. For the students, the partnership allowed them an insight into the world of academia, which is a very unfamiliar environment, particularly for new, incoming first-years. It enabled them to think about the teaching perspective, which was the most evident where 
students were taking on roles such as coaching or mentoring lower-level students, carrying out research, leading induction activities. For staff, the partnership enabled them to think about the learning perspective, which was very evident in the interviews when staff described how they were now thinking about the effectiveness of their previously unchallenged teaching practice and were beginning to look at students through a new lens. Interestingly, the changing of classroom practice could be related to Kahu's structural influence of curriculum and assessment. Whilst the arrows in the framework indicate that SE does not influence structure, the evidence in this study suggests that for staff and students experiencing personal development as a result of partnership working, partnership can lead to the enhancement of curriculum design and delivery. The implication of this for a university wishing to embed institutional curriculum design approaches (such as policy on assessment, employability, etc.) is that cognizance also needs to be taken of agency for change. Encouraging a culture of SaP that can lead to personal development may empower both staff and students to lead this change at the discipline level. Similar findings were echoed in evaluations carried out on staff-student partnerships in different learning contexts, such as inquiry-based learning approaches (Healey \& Jenkins, 2009; Levy et al., 2011), where it was found that the collaborative nature of the approach resulted in enhanced SE and personal development in areas such as changed beliefs and understanding about the roles in learning and knowledge creation.

\section{Challenges}

As outlined earlier, student-staff partnerships are not without their challenges. In this research study, challenges included time, resistance, and capacity (for both students and staff). How these challenges are addressed can differ across the disciplines. Students in particular referred to their busy lives and the struggle to find time to get the balance right between their studies and other activities such as their involvement in partnership activities. For part-time students, involvement in daytime activities was particularly difficult when holding down a full-time job. This is referred to in the framework as "lifeload" and is a critical factor influencing SE (Kahu, 2013) that needs to be considered when determining the nature of partnership work. Knowing who your students are can be enlightening and prompt changes in thinking, as indicated in theme 1 in the findings above. Staff described resistance to partnership as problematic. In this study, resistance was encountered where course teams who were involved in partnership activities did not have full buy-in from their colleagues. Staff described this as unsustainable going forward and suggested reward mechanisms for staff and students developing effective partnership as one way in which sustainability might be achieved (Curran \& Millard, 2015). Additionally, the evidence base to date (see Bryson, 2014b; Cook-Sather et al., 2014; Healey et al., 2014) suggests that if staffstudent partnership is to work then it should become an ethos or a process of engagement; it works best when it becomes a mindset not just at the individual level but at the module, course, discipline, and institution level. However, the challenge of finding a common language can prevail (Levy et al., 2011), and the notion of partnership can be problematic in certain disciplines or for certain individuals. One way to address this might be to focus on partnership as a process or as relational, which Kahu (2013) situates in the psychosocial influences of the framework (Figure 1). As suggested by Matthews (2016), language is important and the recent language of SaP emphasises the more relational form of SE. In other words, conceptualising partnership with a small " $p$ " (i.e., focus on relationship building between staff and students) rather than conceptualising it as a project or with a 
capital "P" (i.e., an extra task or activity outside of class contact time) can be more palatable. In relation to capacity, students explained that sometimes they lack the confidence to know when to speak up or come forward and felt that it can be hard to make a judgment as to whether an idea or suggestion is worthy of consideration. Some students also described a feeling of pressure from being a student partner-pressure to do well academically. Staff described the struggle with letting go-in the sense that they had to know when to give some control to the students. Ceding control was something that perhaps did not happen naturally after years of being in control in a learning and teaching context. In my role as academic developer working with staff and students grappling with partnership, time needs to be taken to allow both to consider what it means to them individually and collectively.

As scaling up partnership working is ongoing at the institution discussed here, we need to consider how this evidence base can inform others, particularly at the curriculum design stage. Using the findings from this study and aligning them to the conceptual framework as discussed allows us to recognize and locate how relational partnerships impact the individual, which in turn can impact the antecedents and consequences of SE (Kahu, 2013).

\section{CONCLUSION}

This research brings new understanding to stakeholders in relation to how the impact of partnership on individual students and staff members can help us think more holistically about SE. Although the sample size in this study is small and from a single institution, thereby limiting generalisability of the findings, there is evidence that the personal development of both students and staff is a welcome outcome of partnership working and one which has the potential to enhance skills, motivation, and self-efficacy of not just students but staff, too. In turn, this personal development can enhance the learning climate, which is important for extending the benefits of partnership working to students beyond the small numbers that tend to put themselves forward. The stage of curriculum design or re-design may be an opportune time for institutions to embed these enhanced learning climates resulting from a SaP ethos. Further key implications from this study in relation to SaP as a process or ethos of SE involves how we conceptualize SE. Using Kahu's (2013) conceptual framework can overlook the potentially transformative impact of the personal development of staff as a result of adopting a SaP approach. Recognizing the three interrelated dimensions of SE can allow institutions to better support staff and students to develop relational partnerships. It is also important to recognize that how staff and students are feeling can act as a catalyst for change in thinking and behaviours. Further additional research needs to be conducted, particularly that which conceptualises SE from both a student and staff perspective, recognising its three dimensions, and the role that SaP plays in building capacity for change. Continuing this research is imperative for developing an evidence base on scaling successful partnership working in specific contexts to an institutional level so that we are prepared for more diverse and increasing student populations.

The research was successfully reviewed according to the university's regulations. 


\section{ACKNOWLEDGEMENTS}

The context for this study was Ulster University's participation in the UK national What Works? Student Retention and Success Change Programme (Thomas et al., 2017). This was funded by the Paul Hamlyn Foundation, co-ordinated by the Higher Education Academy, and Action on Access. I also wish to acknowledge the students and staff involved in this programme at Ulster University from 2013-2016, in particular those that directly participated in this study.

\section{NOTE ON CONTRIBUTOR}

Roisín Curran is a Professional Development Manager at Ulster University. She is a Principal Fellow of the Higher Education Academy and a tutor on the cross-university Postgraduate Certificate in Higher Education Practice. Her teaching focuses on student engagement and curriculum design. She was Project Lead at Ulster in the What Works programme (20132016).

\section{REFERENCES}

Ambrose, S. A., Bridges, M. W., DiPietro, M., Lovett, M.C., \& Norman, K. (2010). How learning works: Seven research-based principles for smart teaching. San Francisco, CA: Jossey Bass.

Aubrey, B. (2010). Managing your aspirations: Developing personal enterprise in the global workplace. Singapore: McGraw-Hill.

Braun, V. \& Clarke, V. (2006). Using thematic analysis in psychology. Qualitative Research in Psychology, 3(2), 77-101. http://dx.doi.org/10.1191/1478088706qp063oa

Bryson, C. (2014a). Clarifying the concept of student engagement. In C. Bryson (Ed.), Understanding and developing student engagement (pp. 1-22). Abingdon: Routledge.

Bryson, C. (2014b). Reflections and considerations about the future of student engagement. In C. Bryson (Ed.), Understanding and developing student engagement (pp. 231240). Abingdon: Routledge.

Coates, H., \& McCormick, A. C. (2014). Student engagement: A window into undergraduate education. In H. Coates, \& A. C. McCormick (Eds.), Engaging university students: International insights from system-wide studies (pp. 1-12). New York: Springer.

Cook, A. (2015). Partnership working across UK public services. Edinburgh: What Works Scotland. Retrieved from http://whatworksscotland.ac.uk/publications/

Cook-Sather, A. (2014). Student-faculty partnership in explorations of pedagogical practice: A threshold concept in academic development. International Journal for Academic Development, 19(3), 186-198. http://dx.doi.org/10.1080/1360144X.2013.805694

Cook-Sather, A., Bovill, C., \& Felten, P. (2014). Engaging students as partners in learning and teaching: A guide for faculty. San Francisco, CA: Jossey-Bass.

Curran, R. \& Millard, L. (2015). A partnership approach to developing student capacity to engage and staff capacity to be engaging: Opportunities for academic developers. International Journal for Academic Development, 21(1), 67-78. http://dx.doi.org/10.1080/1360144X.2015.1120212

Delpish, A., Holmes, A., Knight-McKenna, M., Mihans, R., Darby, A., King, K., \& Felten, P. (2010). Equalising voices: Student-faculty partnership in course design. In C. 
Werder \& M. M. Otis (Eds.), Engaging student voices in the study of teaching and learning (pp. 96-114). Sterling, VA: Stylus Publishing.

Dickerson, C., Jarvis, J., \& Stockwell, L. (2016). Staff-student collaboration: Student learning from working together to enhance educational practice in higher education.

Teaching in Higher Education, 21(3), 249-265.

http://dx.doi.org/10.1080/13562517.2015.1136279

Elder, L. (1996). Critical thinking and emotional intelligence. Inquiry: Critical Thinking Across the Disciplines, 16(2) 35-49. Retrieved from

https://www.pdcnet.org/inquiryct poiesis/content/inquiryct poiesis 199600160 $\underline{00200350049}$

Finlay, L. (2014). Engaging phenomenological analysis. Qualitative Research in Psychology, 11(2), 121-141. http://dx.doi.org/10.1080/14780887.2013.807899.

Moving from the fringe to the mainstream: opportunities for embedding student engagement through partnership. Student Engagement in Higher Education Journal, 1(1). Retrieved from https://journals.gre.ac.uk/index.php/raise/issue/view/46/showToc

Fredricks, J.A., Blumenfeld, P., \& Paris, A. (2004). School engagement: Potential of the concept, state of the evidence. Review of Educational Research, 74(1), 59-109. http://dx.doi.org/10.3102/00346543074001059

Gibbs, G. (2014, May 1). Student engagement, the latest buzzword. Times Higher Education. Retrieved from https://www.timeshighereducation.com/news/studentengagement-the-latest-buzzword/2012947.article

Gibbs. G. (2016). 53 powerful ideas all teachers should know about: "Student engagement" is a slippery concept. Staff and Educational Development Association. Retrieved from: http://www.seda.ac.uk/53-powerful-ideas

Harrington, K., Sinfield, S., \& Burns, T. (2016). Student engagement. In H. Pokorny \& D. Warren (Eds.), Enhancing teaching practice in higher education (pp.106-124). London: Sage.

Healey, M., Flint, A. \& Harrington, K. (2014). Engagement through partnership: students as partners in learning and teaching in higher education. York: HEA. Retrieved from https://www.heacademy.ac.uk/system/files/resources/engagement through part nership.pdf

Healey, M., \& Jenkins, A. (2009). Developing undergraduate research and inquiry. York: Higher Education Academy. Retrieved from:

https://www.heacademy.ac.uk/resource/developing-undergraduate-research-andinquiry

Husserl, E. (1999). The idea of phenomenology (Husserliana: Edmund Husserl - Collected Works). The Netherlands: Kluwer Academic Publications.

Hutchings, C., Bartholomew, N., \& Reilly, O. (2013). Differential student engagement: Lessons learned. In C. Nygaard, S. Brand, P. Bartholomew, \& L. Millard (Eds.), Student engagement: Identity, motivation and community (pp. 125-144).

Faringdon: Libri Publishing.

Kahn, P. (2014). Theorising student engagement in higher education. British Educational Research Journal, 40(6), 1005-1018. http://dx.doi.org/10.1002/berj.3121

Framing student engagement in higher education. Studies in Higher Education, 38(5), 758-

773. http://dx.doi.org/10.1080/03075079.2011.598505

Kvale, S. (2007). Doing interviews. London: Sage. 
Lea, J. (2016). Turning down the volume control on student voice in order to enhance student engagement. Student Engagement in Higher Education Journal, 1(1). Retrieved from https://journals.gre.ac.uk/index.php/raise/issue/view/46/showToc

Levy, P., Little, S. \& Whelan, N. (2011). Perspectives on staff-student partnerships in learning, research and educational enhancement. In S. Little (Ed.), Staff-student partnerships in higher education (pp. 1-15). London: Continuum.

Little, S., Sharp, H., Stanley, L., Hayward, M., Gannon-Leary, P., O’Neill, P. \& Williams, J. (2011). Collaborating for staff-student partnerships: Experiences and observations. In S. Little (Ed.), Staff-student partnerships in higher education (pp. 215-226). London: Continuum.

Marquis, E., Black, C, \& Healey, M. (2017). Responding to the challenges of student-staff partnership: The reflections of participants at an international summer institute. Teaching in Higher Education, 22(6), 720-735 http://dx.doi.org/10.1080/13562517.2017.1289510

Marquis, E., Puri, V., Wan, S., Ahmad, A., Goff, L., Knorr, K., Vassileva, J., \& Woo, J. (2016). Navigating the threshold of student-staff partnerships: A case study from an Ontario teaching and learning institute. International Journal for Academic Development, 21(1), 4-15. http://dx.doi.org/10.1080/1360144X.2015.1113538

Matthews, K.E. (2016). Students as partners as the future of student engagement. Student Engagement in Higher Education Journal, 1(1). Retrieved from https://journals.gre.ac.uk/index.php/raise/issue/view/46/showToc

Mercer-Mapstone, L., Dvorakova, L.S., Matthews, K.E., Abbot, S., Cheng, B., Felten, P., . . . Swaim, K. (2017). A Systematic literature review of students as partners in higher education. International Journal for Students as Partners 1(1). Retrieved from https://mulpress.mcmaster.ca/ijsap/article/view/3119

McCulloch, A. (2009). The student as co-producer: Learning from public administration about the student-university relationship. Studies in Higher Education, 34(2), 171183. http://dx.doi.org/10.1080/03075070802562857

Nygaard, C., Brand, S., Bartholomew, P., \& Millard, L. (Eds.). (2013). Student engagement: Identity, motivation and community. Faringdon: Libri Publishing.

Pauli, R., Raymond-Barker, B., \& Worrell, M. (2016). The impact of pedagogies of partnership on the student learning experience in UK higher education: $A$ psychological perspective. York: Higher Education Academy. Retrieved from https://www.heacademy.ac.uk/resource/impact-pedagogies-partnership-studentlearning-experience-uk-higher-education

Scullion, R., Molesworth, M., \& Nixon, E. (2011). Arguments, responsibility and what is to be done about marketisation. In M. Molesworth, R.Scullion, \& E. Nixon (Eds.), The marketisation of higher education and the student as consumer (pp. 227-236). Oxon: Routledge.

Smith, J.A., Flowers, P., \& Larkin, M. (2009). Interpretative phenomenological analysis. London: Sage.

Solomonides, I. (2013). A relational and multidimensional model of student engagement. In E. Dunne \& D. Owen (Eds.), The student engagement handbook: Practice in higher education (pp. 43-58). Bingley: Emerald Group Publishing Ltd.

Thomas, L. (2012). Building student engagement and belonging in higher education at a time of change: Final report from the What Works? Student Retention \& Success programme. Retrieved from https://www.heacademy.ac.uk/knowledge- 
$\underline{\text { hub/building-student-engagement-and-belonging-higher-education-time-change- }}$ final-report

Thomas, L., Hill, M., O’Mahony, J., \& Yorke, M. (2017). Supporting student success:

Strategies for institutional change: What Works? Student Retention \& Success programme. Retrieved from

https://www.heacademy.ac.uk/system/files/hub/download/what works 2 full report.pdf

Tinto, V. (1987). Leaving college: Rethinking the causes and cures of student attrition. Chicago: University of Chicago Press.

Trowler, V. (2010). Student engagement literature review. York: Higher Education Academy. Retrieved from

https://www.heacademy.ac.uk/sites/default/files/studentengagementliteraturerev iew 1.pdf

van Manen, M. (1990). Researching the lived experience: Human science for an action sensitive pedagogy. New York: State University of New York Press.

Waters, J. (2016). Phenomenological research guidelines. Capilano University.

Retrieved from https://www.capilanou.ca/psychology/student-resources/researchguidelines/Phenomenological-Research-Guidelines/ 